\title{
Aquatic macroinvertebrates associated with Eichhornia azurea (Swartz) Kunth and relationships with abiotic factors in marginal lentic ecosystems (São Paulo, Brazil)
}

\author{
Silva, $C V$ * and Henry, $R$. \\ Department of Zoology, Institute of Biosciences, State University of São Paulo - UNESP, \\ CEP 18618-000, Botucatu, SP, Brazil \\ *e-mail: carolvieira@ibb.unesp.br
}

Received March 12, 2012 - Accepted April 9, 2012 - Distributed February 28, 2013

(With 8 figures)

\begin{abstract}
Marginal lakes are characterised by their having high biological diversity due to the presence of aquatic macrophytes in their coastal zones, providing habitats for refuge and food for animal community members. Among the fauna components associated with macrophytes, aquatic macroinvertebrates are important because they are an energy source for predators and fish. In six lakes and two different seasons (March and August 2009), the ecological attributes of aquatic macroinvertebrate community associated with Eichhornia azurea were compared and the controlling environmental factors were identified. Since the attributes of macroinvertebrate community are strictly associated with abiotic variables of each distinct habitat, our hypothesis was that each site associated with the same floating aquatic macrophyte ( $E$. azurea) should have a typical composition and density of organisms. We identified 50 taxa of macroinvertebrates, with greater taxa richness for aquatic insects ( 37 taxa) divided into eight orders; the order Diptera being the most abundant in the two study periods. On the other hand, higher values of total taxa richness were recorded in August. Dissolved oxygen and $\mathrm{pH}$ presented the greatest number of significant positive correlations with the different taxa. The animals most frequently collected in the six lakes in March and August 2009 were Hirudinea, Oligochaeta, Hydrachnidae, Conchostraca, Ostracoda, Noteridae, Ceratopogonidae, Chironomidae, Culicidae, Caenidae, Pleidae, Aeshnidae, Libellulidae, Coenagrionidae and Nematoda. Only densities of Trichoptera, Ostracoda and Conchostraca presented the highest significant differences between lakes in both study periods and considering the composition of macroinvertebrates no significant differences were registered for macroinvertebrate composition.
\end{abstract}

Keywords: phytofauna, aquatic macrophyte, marginal lakes.

\section{Macroinvertebrados aquáticos associados à Eichhornia azurea (Swartz) Kunth e suas relações com as variáveis abióticas em ecossistemas lênticos marginais (São Paulo, Brasil)}

\section{Resumo}

Lagoas marginais são caracterizadas por apresentar elevada diversidade biológica, devido à presença de macrófitas aquáticas nas suas zonas litorâneas, constituindo habitats de refúgio e alimento para comunidades associadas. Entre os seus integrantes, destacam-se os macroinvertebrados aquáticos, fonte de energia para predadores e ictiofauna. Em seis lagoas e em duas épocas distintas (março e agosto de 2009), os atributos ecológicos da comunidade de macroinvertebrados aquáticos associados à Eichhornia azurea foram comparados, identificando-se os fatores ambientais controladores. Uma vez que os atributos da comunidade de macroinvertebrados estão estritamente associados às variáveis abióticas de cada habitat distinto, nossa hipótese era de que cada local com a presença da mesma macrófita aquática flutuante (E. azurea) deveria ter uma típica composição e densidade de organismos. Foram identificados 50 taxa de macroinvertebrados, com maior riqueza registrada para os insetos aquáticos (37 taxa), distribuídos em oito ordens; sendo a ordem Diptera a mais abundante nos dois períodos de estudo. Por outro lado, maiores valores de riqueza total de taxa foram registrados em agosto. Oxigênio dissolvido e pH apresentaram o maior número de correlações significativas positivas com os diferentes taxa. Os animais mais frequentes, coletados nas seis lagoas estudadas em março e agosto de 2009, foram Hirudinea, Oligochaeta, Hydrachnidiae, Conchostraca, Ostracoda, Noteridae, Ceratopogonidae, Chironomidae, Culicidae, Caenidae, Pleidae, Aeshnidae, Libellulidae, Coenagrionidae e Nematoda. Apenas as densidades de Trichoptera, Ostracoda e Conchostraca apresentaram maior diferença significativa entre lagoas, em ambos os períodos de estudo. Considerando-se a composição de macroinvertebrados, diferenças significativas não foram registradas.

Palavras-chave: fitofauna, macrófitas aquáticas, lagoas marginais. 


\section{Introduction}

Considering the direct contact between littoral regions and the adjacent terrestrial ecosystem, the littoral zone of lakes is characterised by high fauna diversity, because it is colonised by terrestrial as well as by aquatic animals (Takeda et al., 1997). In this transition compartment, a land-water ecotone, a mosaic of ecological niches and several food chains with all the trophic levels, can be recognised (Esteves, 2011).

Aquatic macrophytes are one of the components of the first trophic level at the littoral zone. They are sites for feeding of fish, birds and mammals (Brendonck et al., 2003; Padial et al., 2008) and substrates for spawning, development and emergence of partially aquatic and aquatic insects (Cremona et al., 2008). They provide food and shelter against predators for aquatic macroinvertebrates (Tessier et al., 2004) and young ichthyofauna (SánchezBotero et al., 2007).

Besides their participation in food chains as producers, macrophytes provide food for herbivorous animals. Indirectly, they contribute to the trophic ecology of aquatic ecosystem, being a substrate for periphyton, a food source for invertebrates, which are an energy source for predators and local ichthyofauna.

Macrophytes are also a component of detritivory chain, since, after degradation, they are food for the detritivorous organisms (Bianchini-Junior, 2003). Stripari and Henry (2002), Nessimian and Henriques-de-Oliveira (2005) and Mormul et al. (2006) pointed out a positive relationship in the association of aquatic macroinvertebrate fauna with macrophytes in decomposition.

In addition to the presence of macrophytes in the littoral region supporting macroinvertebrates that live in the roots, some studies have also pointed out a positive relation between this lake compartment and zoobenthos density, as for example, in marginal lakes of the High River Paraná floodplain (Takeda et al., 1997). This observation is evidence of the importance of the littoral zone as a permanence site for macroinvertebrates due to the nutrients dynamics, matter transformation and energy flux in aquatic ecosystems.

One of the great difficulties for biodiversity conservation is the lack of knowledge which prevents the development of actions to support conservation and management strategies. According to De Marco-Junior and Vianna (2005), information lacks results from the inexistence of fauna inventories in many areas, which limits the knowledge of organism distribution and abundance. Due to this information, many of the tools applied to species conservation are little effective or controversial.

Agostinho et al. (2005) showed that the majority of the biodiversity studies in Brazil are related to terrestrial ecosystems and that investigations of aquatic biodiversity tend to be limited to large-size organisms. It is necessary to conduct fauna surveys that also include small size animals for a better understanding of their role in the maintenance and integrity of Brazilian aquatic resources.
The aim of this work was to investigate the taxonomic composition and density of the macroinvertebrate community associated with the aquatic macrophyte Eichhornia azurea in six lakes marginal to the Paranapanema River, as well to examine the influence of environmental variables on its structure and spatial and temporal distributions.

Since the attributes of macroinvertebrate communities are strictly associated with abiotic variables of each distinct habitat, our hypothesis was that each site associated with the same floating aquatic macrophyte (E. azurea) should have a typical composition and density of organisms.

\section{Material and Methods}

\subsection{Study area}

This study was carried out in the municipality of Angatuba, state of São Paulo, in six lakes marginal to Paranapanema River, in the mouth zone of the tributary into the Jurumirim Reservoir (Figure 1).

The mouth zone is a current reduction site of river water (Casanova and Henry, 2004), and laterally, a great number of marginal aquatic environments with different hydrodynamic characteristics (Carmo, 2007) are observed. In this river - reservoir transition region, extensive permanently inundated ecosystems with different degrees of connection with lotic environment are influenced by the variability of hydrologic pulse (Figure 1).

The respective geographical coordinates of the lakes studied, as well as some of the morphometric parameters, obtained from a satellite image in 2010 from Google Earth - version 6.0, using the UTHSCSA Image Tool Program - version 3.0, are presented in Table 1.

\subsection{Sampling and in-laboratory procedure}

The aquatic plant selected for the study was Eichhornia azurea (Swartz) Kunth, a species from the family Pontederiaceae, being commonly locally known as "aguapé". The floating macrophyte presents an extensive and branched system of roots, stems and a great part of the leaves are submersed. In comparison with other macrophyte species, it provides a great diversity of microhabitats for the associated macroinvertebrate communities (Moretti et al., 2003; Mormul et al., 2006; Martello et al., 2008).

Plant samples of three different stands of E. azurea were collected in the six lakes in March and August 2009 using a rectangular sampler with $0.1976-\mathrm{m}^{2}$ area. The sampled material was transferred to plastic bags containing local water and transported to laboratory for removal of the associated fauna.

Aquatic macroinvertebrates were removed after sequentially and consecutively washing the samples in three buckets containing formaldehyde at $8 \%$ and $4 \%$ and only water (Afonso, 2002). The content of each bucket was filtered in a $250-\mu \mathrm{m}$ mesh net and the animals were preserved in a $70 \%$ alcohol solution. Sorting was conducted under a stereoscopic microscope and identification was made using specialised references (Lopretto and Tell, 1995; Mugnai et al., 2010). 


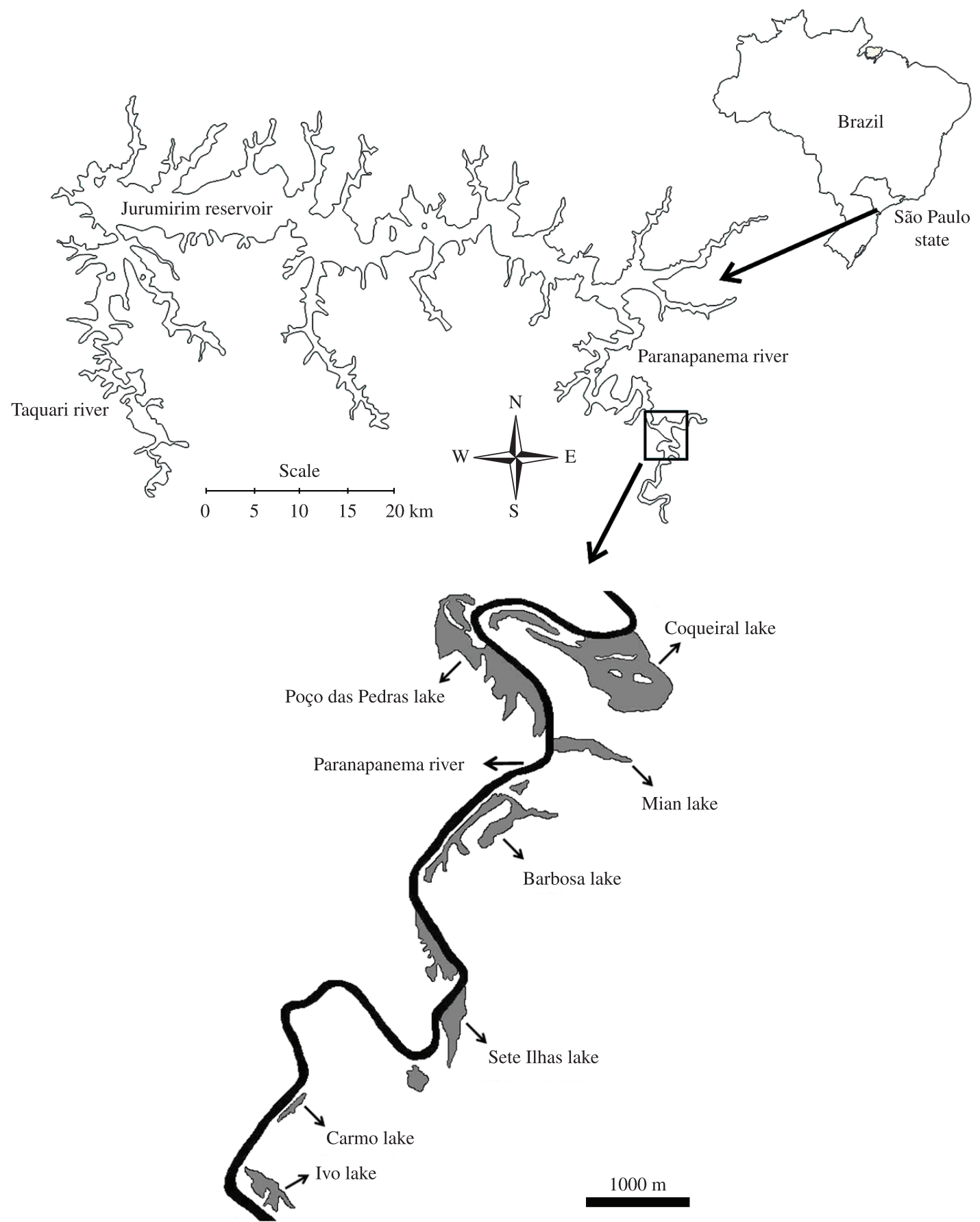

Figure 1. Location of the study area (schema of the lakes marginal to the Paranapanema River, modified from satellite image obtained from Google Earth 2010).

In each of the three sampling sites of each of the six lakes, water samples were also collected at the surface close to the E. azurea stands and the following abiotic variables were determined: dissolved oxygen (Winkler method, modified by Golterman et al., 1978), $\mathrm{pH}$ (with a Micronal B-380 pHmeter), conductivity (with a Hach-2511 conductivimeter), total suspended solids (Teixeira and
Kutner, 1962), water temperature (with a Toho Dentam ET-3 thermistor), and transparency (by a Secchi disk).

\subsection{Data analysis}

Firstly, mean $(\mathrm{N}=3)$ and standard deviation of abiotic and biotic variables of each lake were computed. In order to examine statistically significant differences $(\mathrm{p}<0.05)$ 
between the attributes of macroinvertebrates fauna associated with the plant and abiotic variables of the studied lakes in the two sampling periods, Kruskal-Wallis non-parametric variance analysis was made and completed with the Tukey test (when significant differences were found) using the Sigma Plot.11 program, when the premises of normality and homocedasticity were no verified.

Next, principal component analysis (PCA) was carried out using the PC-ORD 4.14 program. The analysis was conducted in order to determine abiotic variables having the greatest significance in this study and to obtain the ordination of variables between lakes and study periods considering the mean values $(\mathrm{N}=3)$ of each lake.

To obtain the significant correlations between the densities of macroinvertebrates associated with the plants in each lake and the abiotic variables, a Spearman correlation matrix was made using the Statistica 7 program (Statsoft 2009).

All the statistical tests were carried out using $\log (\mathrm{x}+1)$ transformed data, except for $\mathrm{pH}$ values.

The density of macroinvertebrates was computed from the total count of individuals in the sample and was expressed by unit area $\left(\mathrm{m}^{2}\right)$, and dominance in the macroinvertebrate community in the studied lakes was determined using the Simpson dominance index (Odum and Barrett, 2007).

\section{Results}

\subsection{Abiotic variables}

Mean annual precipitation was $1,224.5 \mathrm{~mm}$ in the period from 1999 to 2008, and during the period of our study (2009) it was $1,887.6 \mathrm{~mm}$. Distribution of monthly precipitation during the year showed that the accumulated total in July 2009 (month prior to the second sampling) was approximately three times higher than the historic monthly mean between 1999 and 2008 (Figure 2). Thus, it can be concluded that 2009 was an "atypical" year in relation to rainfall. Considering the hydrometric levels variation between seasons, a difference of $0.86 \mathrm{~m}$ (566.43 and $567.29 \mathrm{~m}$, in rainy and dry periods respectively) was observed.

Dissolved oxygen in water, total suspended solids, electrical conductivity and $\mathrm{pH}$ presented the highest values in August 2009 (Figure 3). Kruskal-Wallis analysis, completed with the Tukey test, pointed out that seasonal and spatial significant differences $(\mathrm{p}<0.05)$ existed for all the environmental variables, especially for water temperature, dissolved oxygen, and total suspended solids (Figure 3).

Principal component analysis (PCA), involving abiotic variables of the six lakes measured in March and August 2009, explained $62.0 \%$ of data variance (axis 1: $38.9 \%$ and axis $2: 23.1 \%$ ). Graphic ordination originated after the analysis showed a clear distinction between the studied lakes in the two periods of the year (Figure 4). Considering the greater percentage of data variance explanation and the highest positive correlation of $\mathrm{pH}$ and dissolved oxygen with axis 1 (Table 2 ), these variables were the best explaining parameters of the ordination of lakes and periods in the analysis.

\subsection{Macroinvertebrates community associated with E. azurea}

3.2.1. Taxonomic composition, occurrence constancy and dominance

Higher values of taxonomic richness were recorded in August and from a total of 50 taxa identified, the most frequent with $100 \%$ of occurrence were Hirudinea, Oligochaeta, Hydrachnidiae, Conchostraca, Ostracoda, Noteridae, Ceratopogonidae, Chironomidae, Culicidae, Caenidae, Pleidae, Aeshnidae, Libellulidae, Coenagrionidae and Nematoda.

Total taxa richness was higher in August than in March in all the sampled sites, the greatest value being recorded in Lakes Ivo and Poço das Pedras. Conversely, the Simpson dominance index presented higher values in the majority of the lakes in March than August (Figure 5).

\subsubsection{Density}

The mean total density of macroinvertebrates in March was higher in Poço das Pedras Lake (12,088 ind. ${ }^{-2}$ ) and

Table 1. General characterisation of the lakes studied.

\begin{tabular}{|c|c|c|c|c|c|c|}
\hline Lakes & $\begin{array}{r}\text { Area } \\
\left(\mathbf{k m}^{2}\right)\end{array}$ & $\begin{array}{c}\text { Maximum length } \\
(\mathbf{k m})\end{array}$ & $\begin{array}{c}\text { Maximum width } \\
(\mathbf{k m})\end{array}$ & $\begin{array}{c}\text { Perimeter } \\
(\mathbf{k m})\end{array}$ & $\begin{array}{c}\text { Shore } \\
\text { development }\end{array}$ & $\begin{array}{l}\text { Geographic } \\
\text { coordinates }\end{array}$ \\
\hline Ivo & 0.068 & 0.66 & 0.28 & 2.275 & 2.44 & $\begin{array}{l}23^{\circ} 31^{\prime} 57.0^{\prime \prime} \mathrm{S} \\
48^{\circ} 38^{\prime} 53.7^{\prime \prime} \mathrm{W}\end{array}$ \\
\hline Carmo & 0.023 & 0.46 & 0.07 & 1.085 & 1.98 & $\begin{array}{l}23^{\circ} 31^{\prime} 49.8^{\prime \prime} \mathrm{S} \\
48^{\circ} 38^{\prime} 54.6^{\prime \prime} \mathrm{W}\end{array}$ \\
\hline Sete Ilhas & 0.074 & 0.70 & 0.20 & 1.665 & 1.71 & $\begin{array}{l}23^{\circ} 31^{\prime} 46.7^{\prime \prime} \mathrm{S} \\
48^{\circ} 38^{\prime} 14.4^{\prime \prime} \mathrm{W}\end{array}$ \\
\hline Barbosa & 0.203 & 1.42 & 0.55 & 6.270 & 3.90 & $\begin{array}{l}23^{\circ} 30^{\prime} 22.3{ }^{\prime \prime} \mathrm{S} \\
48^{\circ} 37^{\prime} 45.6 " \mathrm{~W}\end{array}$ \\
\hline $\begin{array}{l}\text { Poço das } \\
\text { Pedras }\end{array}$ & 0.371 & 1.63 & 0.72 & 6.737 & 3.10 & $\begin{array}{l}23^{\circ} 29^{\prime} 30.1^{\prime \prime} \mathrm{S} \\
48^{\circ} 37^{\prime} 50.6 " \mathrm{~W}\end{array}$ \\
\hline Coqueiral & 0.582 & 1.62 & 0.75 & 6.663 & 2.44 & $\begin{array}{lll}23^{\circ} 29^{\prime} & 24.4^{\prime \prime} \mathrm{S} \\
48^{\circ} 37^{\prime} & 28.9^{\prime \prime} \mathrm{W}\end{array}$ \\
\hline
\end{tabular}




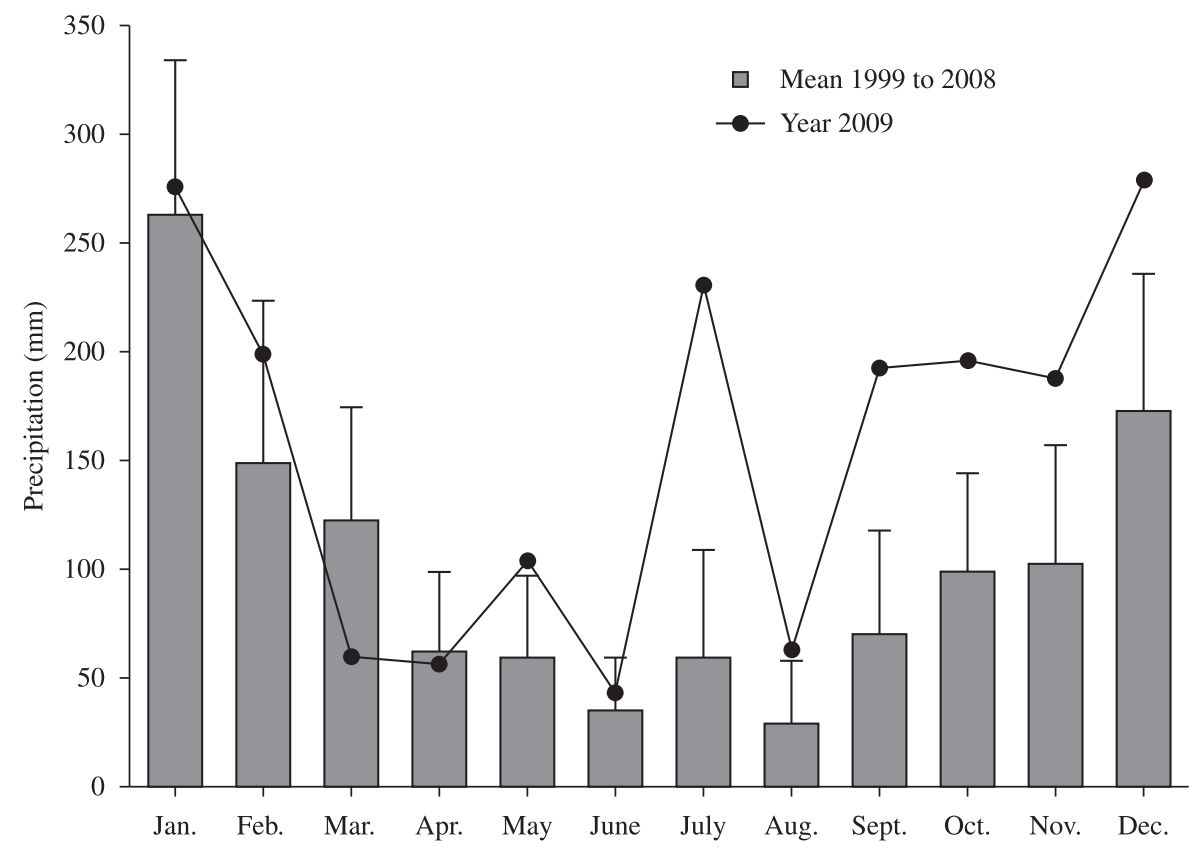

Figure 2. Variations of monthly-accumulated precipitation during 2009 compared with the mean values and standard deviations of monthly historic series (from 1999 to 2008) of precipitation recorded at Angatuba Town.

lower in Carmo Lake (4,082 ind. $\left.\mathrm{m}^{-2}\right)$, while in August the highest mean total density was recorded in Sete Ilhas Lake $\left(14,293\right.$ ind. $\left.\mathrm{m}^{-2}\right)$ and the lowest in Coqueiral Lake $\left(6,280\right.$ ind. $\left.\mathrm{m}^{-2}\right)$ (Figure 6).

In both periods, the Class Insecta was the most abundant, followed by the Phylum Crustacea and the Class Clitella. Other taxa were little abundant, presenting different numeric participation in the six lakes (Figure 7).

In March, the order Diptera predominated over the remaining orders of aquatic insects, being Chironomidae the taxa with the highest density of dipterans (Figure 7). In same period, the order Odonata had also an important contribution, being followed by Diptera, a more abundant order in Lakes Ivo (391 ind. $\mathrm{m}^{-2}$ ), Carmo (180 ind. $\mathrm{m}^{-2}$ ), Sete Ilhas (234 ind. $\mathrm{m}^{-2}$ ) and Barbosa (285 ind. $\mathrm{m}^{-2}$ ). Little abundant insects were from orders Lepidoptera and Collembola.

In August, the components of order Diptera were also the most abundant organisms and Chironomidae predominated in all the studied lakes; densities ranged from 3,656 ind. $\mathrm{m}^{-2}$ (Ivo Lake) to 7,554 ind. $\mathrm{m}^{-2}$ (Sete Ilhas Lake). Besides Chironomidae, Cerapotogonidae, pupae of Diptera and Culicidae showed high abundance, in this decreasing order.

In relation to the other orders of aquatic insects, the most abundant were Trichoptera (1,162 ind. $\left.\mathrm{m}^{-2}\right)$, Ephemeroptera $\left(1,108\right.$ ind. $\left.\mathrm{m}^{-2}\right)$ and Odonata $\left(287\right.$ ind. $\left.\mathrm{m}^{-2}\right)$ in Sete Ilhas Lake, while the lowest densities corresponded to orders Ephemeroptera (203 ind. $\mathrm{m}^{-2}$ ) and Odonata (116 ind. $\mathrm{m}^{-2}$ ), recorded in Coqueiral Lake, and Trichoptera (194 ind. $\mathrm{m}^{-2}$ ), in Carmo Lake.
Order Collembola was the least abundant, but comparing the two studied periods, in August abundance was higher (Figure 8).

Ostracoda and Conchostraca were the Crustacea taxa identified in this study. Ostracoda was the most abundant taxa considering temporal and spatial variations, except in one lake, Sete Ilhas Lake. In this environment, the densities of Ostracoda ranged from 81 (March) to 455 ind. $\mathrm{m}^{-2}$ (August), while those of Conchostraca were 1,648 and 1,690 ind. $\mathrm{m}^{-2}$, respectively.

Clitellata was represented by the subclasses Hirudinea and Oligochaeta. Organisms from Oligochaeta were the most abundant in the six sampled lakes in both periods. The highest density was recorded in Ivo Lake in August $\left(1,306\right.$ ind. $\left.\mathrm{m}^{-2}\right)$. For Hirudinea, the abundance $\left(142\right.$ ind. $\left.\mathrm{m}^{-2}\right)$ was also the highest in Carmo Lake in August.

In relation to Superorder Acariformes, mean densities varied between lakes and periods. Hydrachnidiae presented the highest abundance in all lakes and periods. Spatially, the highest value was found in Lake Poço da Pedra (135 and 309 ind. $\mathrm{m}^{-2}$ in March and August, respectively).

Considering the class Gastropoda, Planorbidae was the prominent taxa. In March, the highest density was recorded in Ivo Lake (592 ind. $\mathrm{m}^{-2}$ ) and in August in Lakes Barbosa and Coqueiral (224 ind. $\mathrm{m}^{-2}$ ). Conversely, the lowest abundances were obtained for Ampulariidae in Lakes Ivo (5 ind. $\left.\mathrm{m}^{-2}\right)$ and Carmo (2 ind. $\left.\mathrm{m}^{-2}\right)$. For the bivalves of family Sphaeriidae, the highest densities were found in Barbosa Lake (401 and 275 ind. $\mathrm{m}^{-2}$ in March and August, respectively).

Water dissolved oxygen and $\mathrm{pH}$ presented a great number of positive correlations with the different taxa 

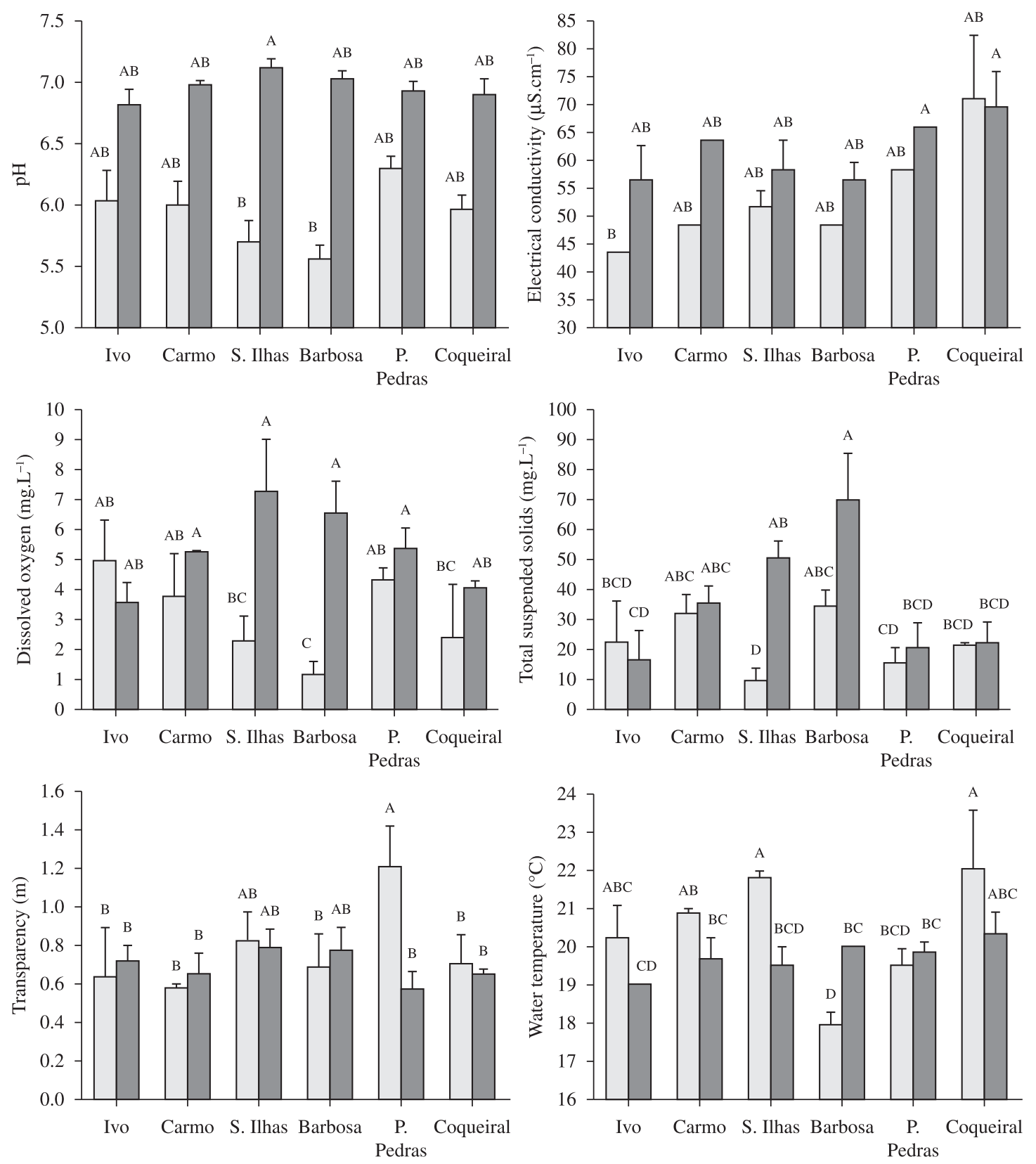

$$
\square \text { March } \square \text { August }
$$

Figure 3. Mean $(\mathrm{N}=3)$ values and standard-deviations of abiotic variables in the lakes studied in March and August 2009. Bars with at least one similar letter present no significant differences (Tukey test; $\mathrm{p}<0.05$ ).

(Table 3). Richness also showed a positive correlation with $\mathrm{pH}$ and dissolved oxygen. Conversely, dominance of macroinvertebrates community associated with E. azurea correlated negatively only with dissolved oxygen.

Caenidae was the taxa that presented the highest number of correlations with the environmental variables. Considering the taxa of greater importance in the present study, Chironomidae presented a positive correlation only with water transparency and Oligochaeta, a negative correlation only with water temperature.

In terms of the variation of total density of the main macroinvertebrates between the lakes in the two periods, the Kruskal-Wallis analysis pointed out significant differences ( $\mathrm{p}<0.05)$ for Ephemeroptera, Hemiptera, Lepidoptera, Trichoptera, Conchostraca, Ostracoda and Nematoda. After the Tukey test, it was verified that the taxa with the highest 


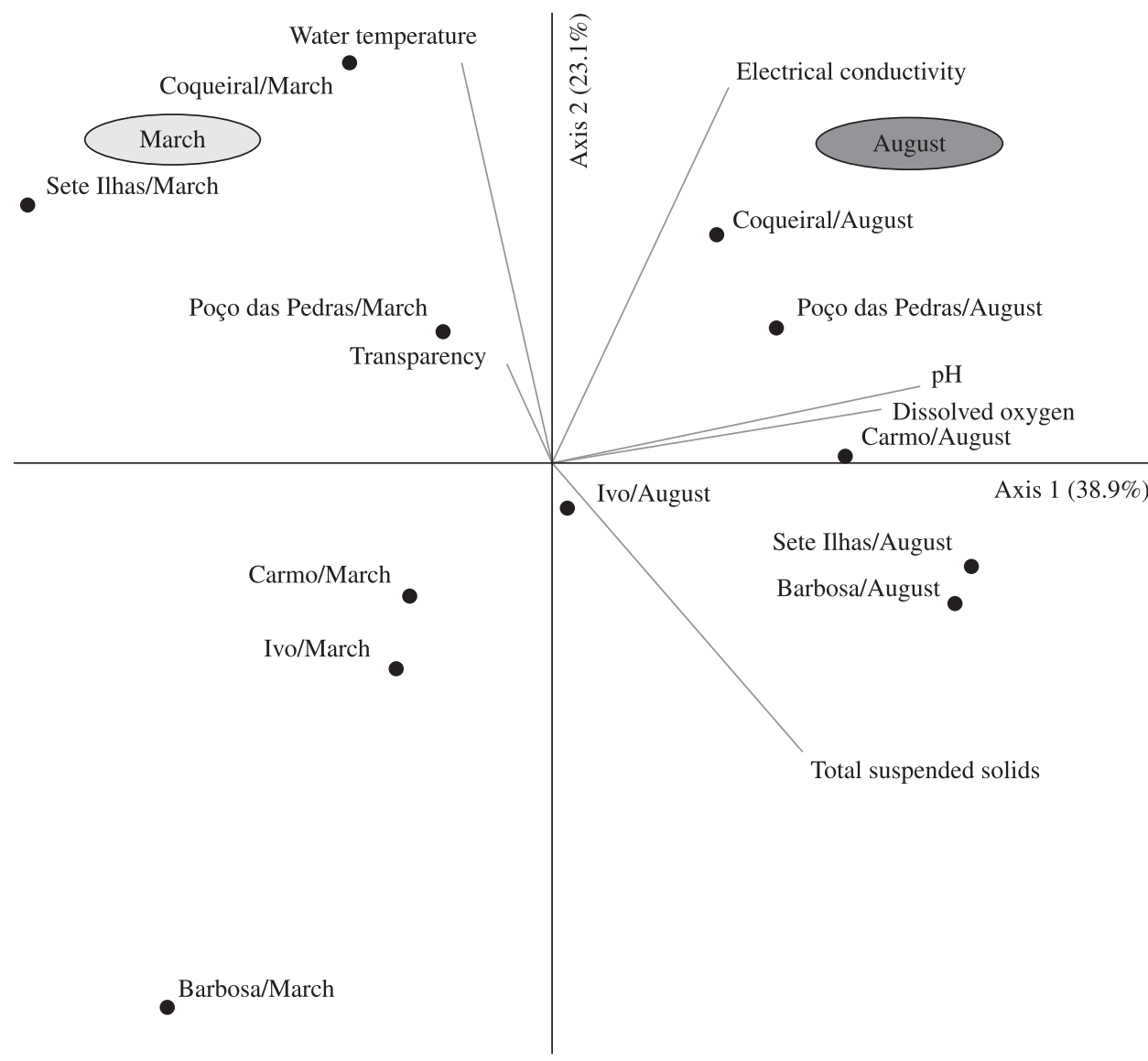

Figure 4. Ordination of environmental variables measured in the six lakes and two periods with axes 1 and 2 of Principal Component Analysis.

Table 2. Scores of correlations of environmental variables measured in six lakes in March and August 2009, with the first two axes of Principal Component Analysis.

\begin{tabular}{lrr}
\hline \multicolumn{1}{c}{$\begin{array}{c}\text { Environmental } \\
\text { variables }\end{array}$} & Axis 1 & Axis 2 \\
\hline $\mathrm{pH}$ & 0.954 & 0.144 \\
Dissolved oxygen & 0.851 & 0.101 \\
Total suspended solids & 0.649 & -0.535 \\
Electrical conductivity & 0.457 & 0.698 \\
Water temperature & -0.232 & 0.741 \\
Transparency & -0.122 & 0.184 \\
\hline
\end{tabular}

significant differences between lakes in the periods studied were Trichoptera, Ostracoda and Conchostraca (Table 4).

\section{Discussion}

According to Henry and Costa (2003), intensity and frequency of inundation pulses in marginal lakes are related to the localization of lentic ecosystems in floodplains and to the degree of connection with rivers. Such factors affect the limnological characteristics of these sites, considering that marginal lakes are very susceptible to flood and drought events.

The present study was carried out during an "atypical" year, considering the precipitation regime. Despite the peculiar rainfall regime in 2009 , an influence of hydrometric level variation was detected, especially in August, after a high rainfall in the previous month. Although the great water volume accumulated in the Jurumirim Reservoir can act as a buffer system to lateral inundation of the Paranapanema River, differently from natural floodplain systems (Henry, 2005), Granado and Henry (2008) showed that, in the same studied region, abiotic changes of water in marginal lakes are affected by the variation of hydrometric levels. Thus, inundations caused by flood events modify the metabolism of marginal ecosystems as well as of inhabiting aquatic organism communities (Tundisi and Matsumura-Tundisi, 2008).

Taxa richness of macroinvertebrates associated with E. azurea presented the highest values in all lakes in August, when the degree of connection of the marginal lakes with the Paranapanema River was high, due to the influence of the hydrometric levels as a result of the increase in the water lateral inflow from the river. In August, the better oxygenation of water, when compared with March values, and $\mathrm{pH}$ near neutrality were probably the key factors favourable 


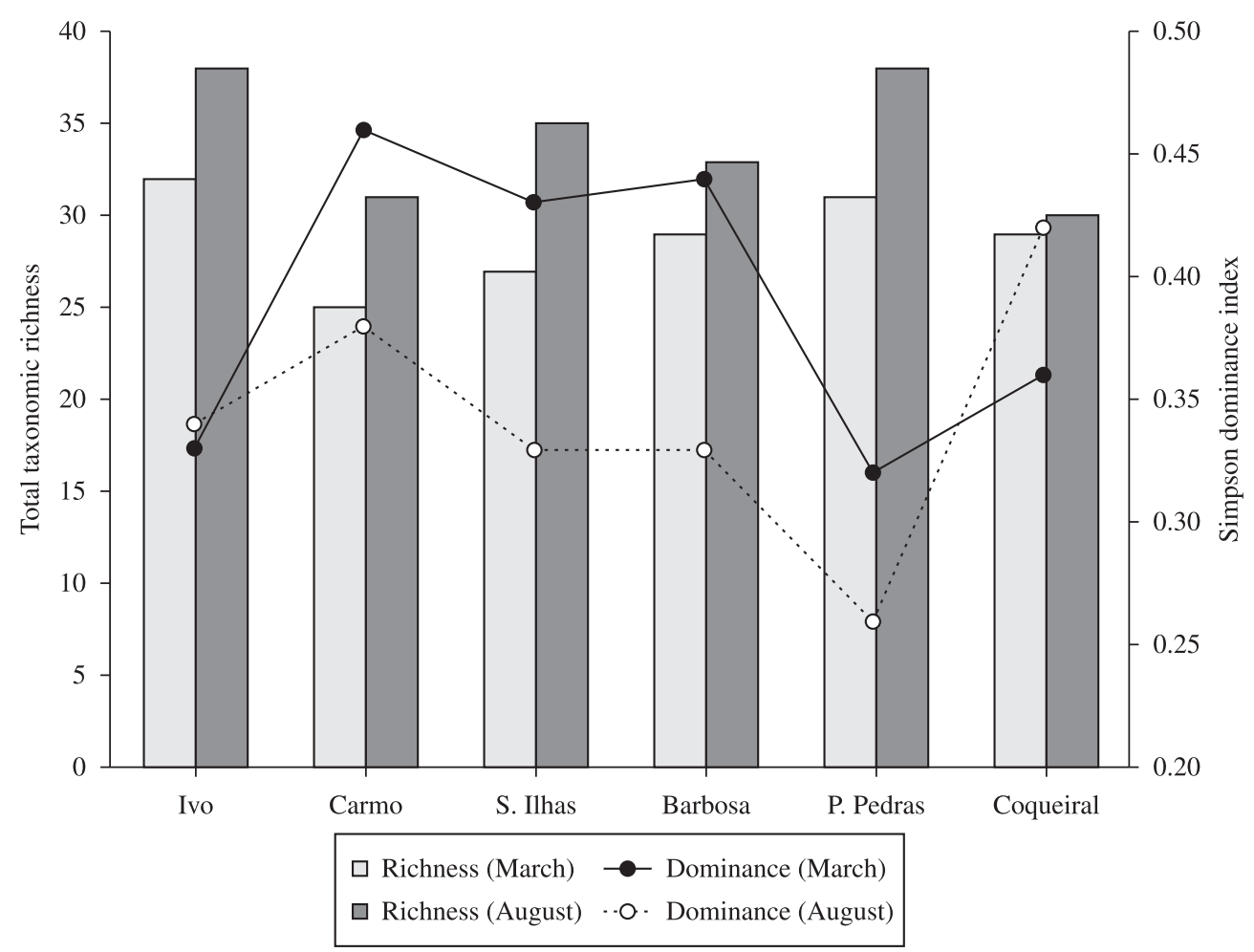

Figure 5. Taxa total richness and dominance indexes of macroinvertebrate communities associated with E. azurea in the lakes studied in March and August 2009.

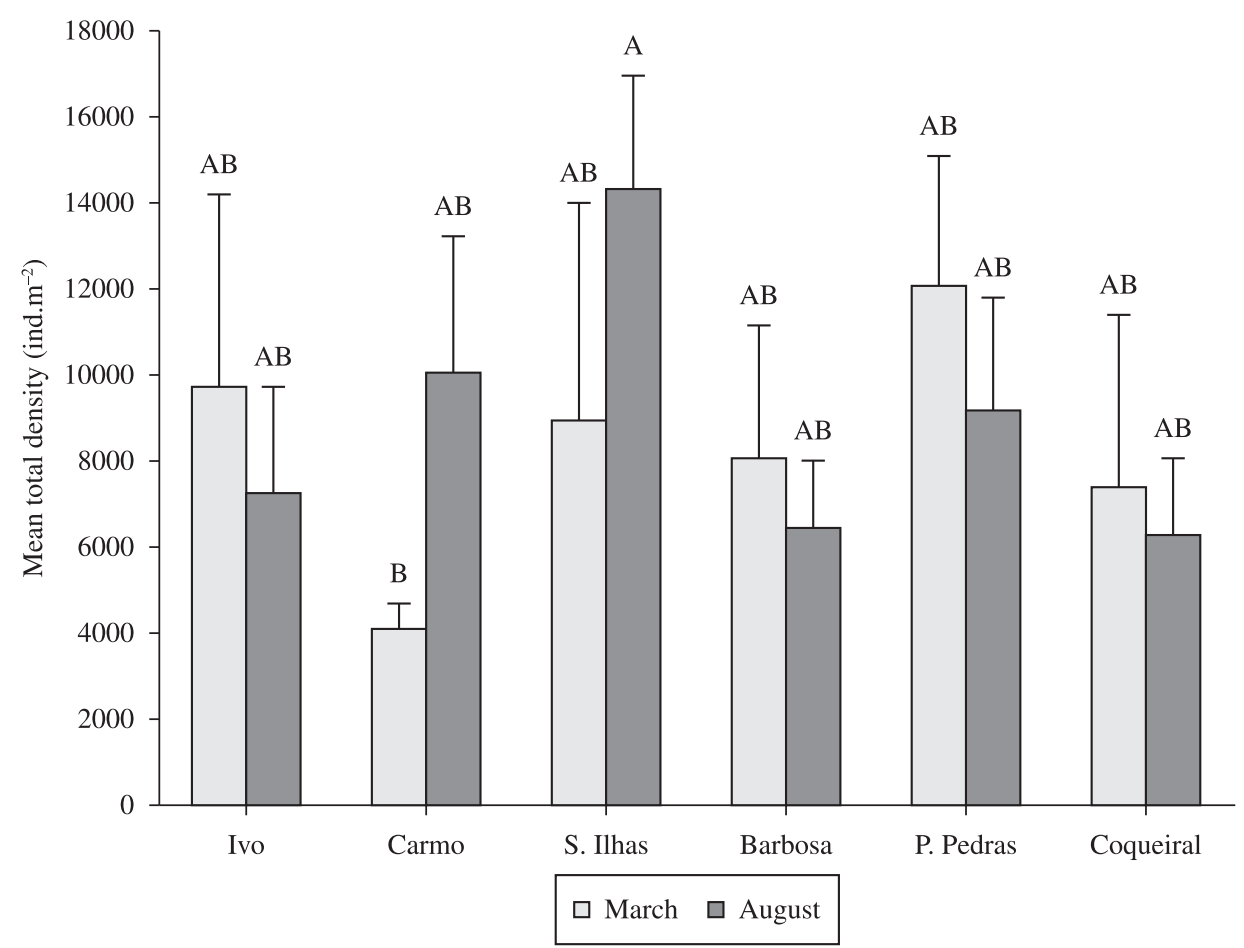

Figure 6. Mean $(\mathrm{N}=3)$ total densities and standard-deviations of macroinvertebrates in the lakes studied in March and August 2009. Bars with at least one similar letter presented no significant difference (Tukey test; $\mathrm{p}<0.05$ ). 

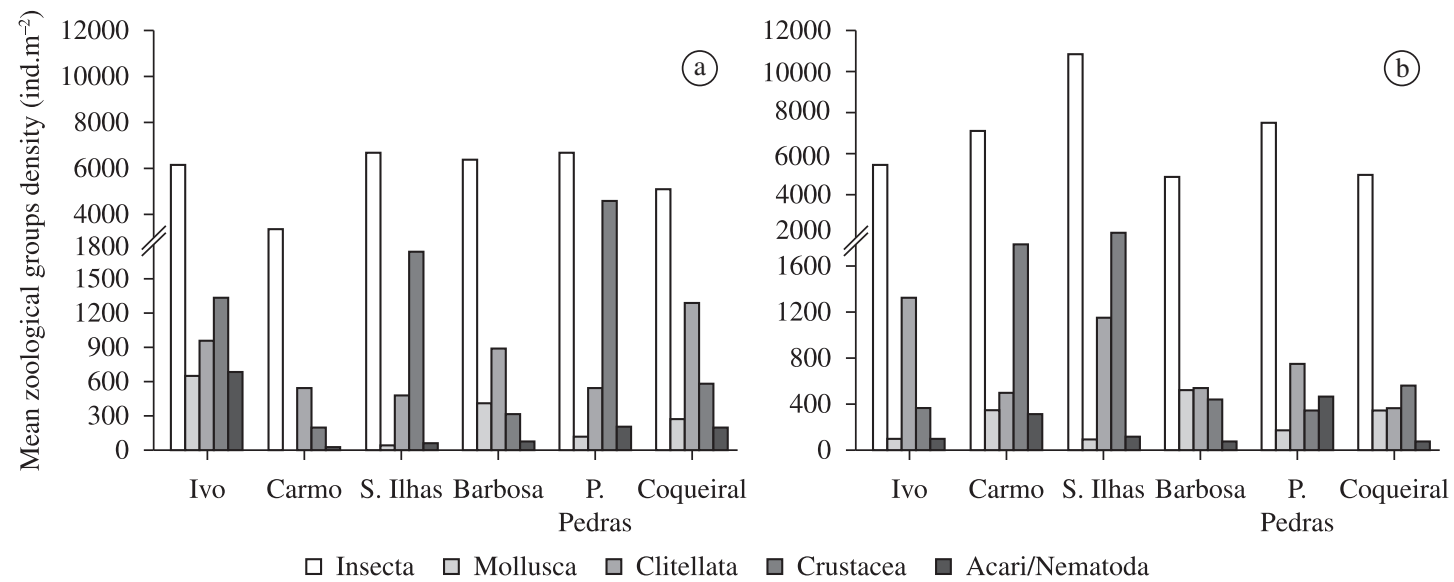

Figure 7. Mean $(\mathrm{N}=3)$ density of zoological groups recorded in the lakes studied in March (a) and August (b) 2009.
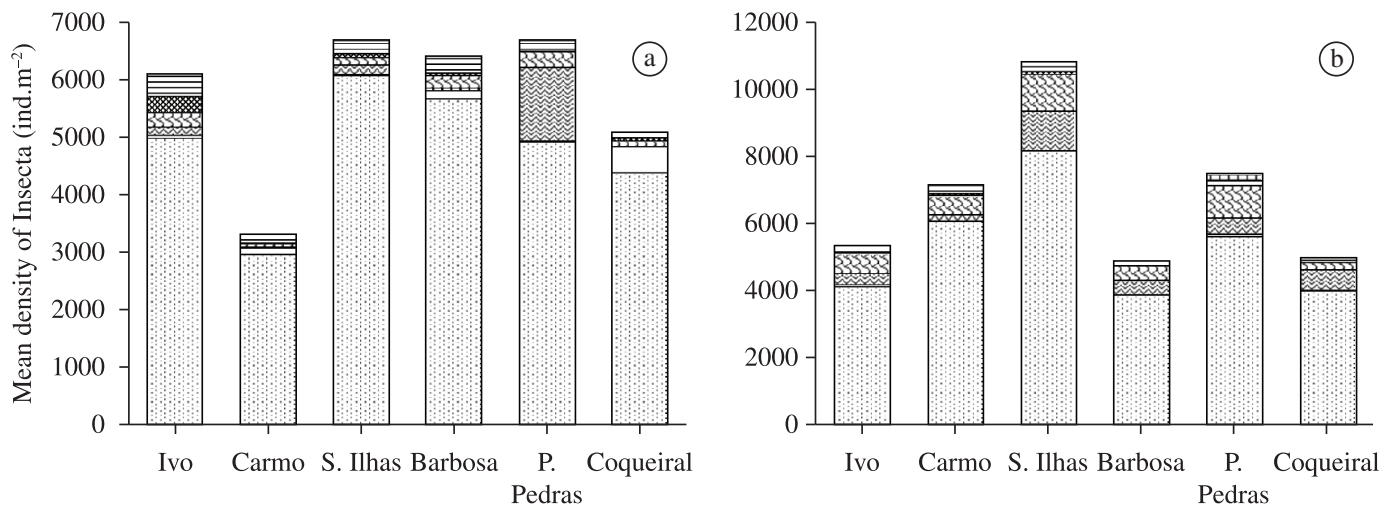

\begin{tabular}{|ll|}
\hline Diptera & Hemiptera \\
Coleoptera & Odonata \\
Trichoptera & Lepidoptera \\
Ess Ephemeroptera & Collembola \\
\hline
\end{tabular}

Figure 8. Mean density of aquatic insects recorded in the lakes studied in March (a) and August (b) 2009 (Note the difference of scales in figures a and $b$ ).

to the occurrence of a great number of macroinvertebrate taxa, as shown by the Spearman correlation analysis. In August, the E. azurea stands presented individuals in senescence phase. This occurrence originated many micro-habitats and the enlargement of ecological niches for macroinvertebrates, because the decomposition detritus released provided food resources for the detritivorous chain. During the degradation process, an immediate reduction in the amounts of polyphenols stored in the tissues of $E$. azurea occurred and the remaining plant matter became more palatable for the macroinvertebrates (Stripari and Henry, 2002). During macrophyte decomposition, bacteria and fungi colonise the plants first and nitrogen and protein concentrations increase in the substrate in degradation, making the produced food more attractive to invertebrates. Thus, macrophytes in senescent stages appear to be a very important food resource to macroinvertebrates. Gonçalves Junior et al. (2004) also found a positive relationship of macroinvertebrates richness associated with macrophytes in senescent stage of decomposition.

Dajoz (2005) proposed that "perturbations with low amplitudes increase environment heterogeneity and can produce an increase on communities diversity". The rainfall regime in 2009 caused a natural instability that altered the habitats and thus modified the richness of biota present. According to Lake (2000) natural disturbances caused by variations in water level have great influence on environmental variables and the biota, causing changes in the composition of species.

In addition, McCabe and Gotelli (2000) found a gradual increase in richness associated with disturbance intensity in a study on the impact of physical disturbance on the colonisation of macroinvertebrates in artificial substrates.

Considering that in this study the substrate of the macroinvertebrates consisted of aquatic macrophytes, the uncommon rainfall in July, a month of dry season, probably caused a disturbance in the natural substrate, resulting in higher taxa richness in August when compared to March. 
Table 3. Spearman correlations $(r, \alpha=0.05)$ between environmental variables $\mathrm{pH}$, electrical conductivity (EC), dissolved oxygen (DO), total suspended solids (TSS), transparency (T) and water temperature (WT) with ecological attributes and taxa of macroinvertebrate communities in six lakes in March and August 2009.

\begin{tabular}{|c|c|c|c|c|c|c|c|}
\hline & & pH & EC & DO & TSS & $\mathbf{T}$ & WT \\
\hline \multirow[t]{2}{*}{ Dominância } & $\mathbf{r}$ & & & -0.428 & & & \\
\hline & $\mathbf{p}$ & & & 0.009 & & & \\
\hline \multirow[t]{2}{*}{ Riqueza } & $\mathbf{r}$ & 0.394 & & 0.366 & & & -0.381 \\
\hline & $\mathbf{p}$ & 0.017 & & 0.028 & & & 0.022 \\
\hline \multirow[t]{2}{*}{ Densidade } & $\mathbf{r}$ & & & & & 0.430 & \\
\hline & $\mathbf{p}$ & & & & & 0.009 & \\
\hline \multicolumn{8}{|l|}{ Acariformes } \\
\hline \multirow[t]{2}{*}{ Hydrachnidiae } & $\mathbf{r}$ & 0.377 & & 0.496 & & & \\
\hline & p & 0.023 & & 0.002 & & & \\
\hline \multirow[t]{2}{*}{ Oribatida } & $\mathbf{r}$ & 0.470 & & 0.488 & & & \\
\hline & $\mathbf{p}$ & 0.004 & & 0.003 & & & \\
\hline \multicolumn{8}{|l|}{ Annelida } \\
\hline \multirow[t]{2}{*}{ Hirudinea } & $\mathbf{r}$ & -0.347 & & & & -0.423 & \\
\hline & p & 0.038 & & & & 0.010 & \\
\hline \multirow[t]{2}{*}{ Oligochaeta } & $\mathbf{r}$ & & & & & & -0.396 \\
\hline & $\mathbf{p}$ & & & & & & 0.017 \\
\hline \multicolumn{8}{|l|}{ Crustacea } \\
\hline \multirow[t]{2}{*}{ Conchostraca } & $\mathbf{r}$ & & -0.355 & & & & \\
\hline & $\mathbf{p}$ & & 0.034 & & & & \\
\hline \multicolumn{8}{|l|}{ Collembola } \\
\hline \multirow[t]{2}{*}{ Isotomidae } & $\mathbf{r}$ & 0.493 & 0.547 & & & & \\
\hline & $\mathbf{p}$ & 0.002 & 0.001 & & & & \\
\hline \multicolumn{8}{|l|}{ Coleoptera } \\
\hline \multirow[t]{2}{*}{ Gyrinidae } & $\mathbf{r}$ & & & & -0.376 & 0.379 & \\
\hline & $\mathbf{p}$ & & & & 0.024 & 0.023 & \\
\hline \multirow[t]{2}{*}{ Noteridae } & $\mathbf{r}$ & -0.547 & & -0.441 & & & 0.349 \\
\hline & $\mathbf{p}$ & 0.001 & & 0.007 & & & 0.037 \\
\hline \multirow[t]{2}{*}{ Scirtidae } & $\mathbf{r}$ & 0.508 & 0.344 & & & & \\
\hline & p & 0.002 & 0.040 & & & & \\
\hline \multicolumn{8}{|l|}{ Diptera } \\
\hline \multirow[t]{2}{*}{ Diptera (pupa) } & $\mathbf{r}$ & & & & & & -0.442 \\
\hline & $\mathbf{p}$ & & & & & & 0.007 \\
\hline \multirow[t]{2}{*}{ Chironomidae } & $\mathbf{r}$ & & & & & 0.471 & \\
\hline & $\mathbf{p}$ & & & & & 0.011 & \\
\hline Culicidae & $\mathbf{r}$ & 0.587 & 0.439 & 0.428 & & & \\
\hline & $\mathbf{p}$ & $<0.001$ & 0.007 & 0.009 & & & \\
\hline Muscidae & $\mathbf{r}$ & -0.450 & & -0.442 & & & -0.498 \\
\hline & $\mathbf{p}$ & 0.006 & & 0.007 & & & 0.002 \\
\hline Stratiomyidae & $\mathbf{r}$ & & 0.557 & & & & \\
\hline & p & & $<0.001$ & & & & \\
\hline Ephemeroptera & & & & & & & \\
\hline Baetidae & $\mathbf{r}$ & & & & & -0.522 & \\
\hline & $\mathbf{p}$ & & & & & 0.001 & \\
\hline Caenidae & $\mathbf{r}$ & 0.666 & 0.381 & 0.632 & 0.343 & & -0.450 \\
\hline & $\mathbf{p}$ & $<0.001$ & 0.022 & $<0.001$ & 0.041 & & 0.006 \\
\hline Polymitarcyidae & $\mathbf{r}$ & -0.478 & -0.357 & & & 0.370 & \\
\hline & $\mathbf{p}$ & 0.003 & 0.033 & & & 0.026 & \\
\hline Hemiptera & & & & & & & \\
\hline Belostomatidae & $\mathbf{r}$ & & 0.373 & & & & \\
\hline & $\mathbf{p}$ & & 0.025 & & & & \\
\hline
\end{tabular}


Table 3. Continued...

\begin{tabular}{|c|c|c|c|c|c|c|c|}
\hline & & pH & EC & DO & TSS & $\mathbf{T}$ & WT \\
\hline \multicolumn{8}{|l|}{ Hemiptera } \\
\hline \multirow[t]{2}{*}{ Corixidae } & $\mathbf{r}$ & & & 0.390 & & & \\
\hline & p & & & 0.019 & & & \\
\hline \multirow[t]{2}{*}{ Mesovellidae } & $\mathbf{r}$ & 0.492 & & 0.431 & 0.343 & & \\
\hline & p & 0.002 & & 0.009 & 0.040 & & \\
\hline \multirow[t]{2}{*}{ Notonectidae } & $\mathbf{r}$ & & & & 0.502 & & \\
\hline & $\mathbf{p}$ & & & & 0.002 & & \\
\hline \multicolumn{8}{|l|}{ Lepidoptera } \\
\hline \multirow[t]{2}{*}{ Lepidotpera (n.i.) } & $\mathbf{r}$ & & & & & & -0.371 \\
\hline & $\mathbf{p}$ & & & & & & 0.026 \\
\hline \multicolumn{8}{|l|}{ Trichoptera } \\
\hline \multirow[t]{2}{*}{ Hydroptilidae } & $\mathbf{r}$ & 0.677 & & 0.646 & & & \\
\hline & p & $<0.001$ & & $<0.001$ & & & \\
\hline \multicolumn{8}{|l|}{ Bivalvia } \\
\hline \multirow[t]{2}{*}{ Sphaeriidae } & $\mathbf{r}$ & & 0.375 & & & & \\
\hline & $\mathbf{p}$ & & 0.024 & & & & \\
\hline \multicolumn{8}{|l|}{ Gastropoda } \\
\hline \multirow[t]{2}{*}{ Physidae } & $\mathbf{r}$ & & & 0.443 & & & \\
\hline & p & & & 0.007 & & & \\
\hline \multirow[t]{2}{*}{ Planorbidae } & $\mathbf{r}$ & 0.397 & & & & & \\
\hline & $\mathbf{p}$ & 0.017 & & & & & \\
\hline
\end{tabular}

Table 4. Results of Kruskal-Wallis analysis with complementary Tukey test for density of macroinvertebrate communities (at the level of great groups) associated with E. azurea in the six lakes measured in March and August 2009. Equal letters in the same line corresponding to each taxon indicate no significant difference between sites and periods and an asterisk indicates difference not detected by the complementary test.

\begin{tabular}{|c|c|c|c|c|c|c|c|c|c|c|c|c|}
\hline \multirow{2}{*}{ Taxa } & \multicolumn{2}{|c|}{ Ivo } & \multicolumn{2}{|c|}{ Carmo } & \multicolumn{2}{|c|}{ Sete Ilhas } & \multicolumn{2}{|c|}{ Barbosa } & \multicolumn{2}{|c|}{ Poço da Pedra } & \multicolumn{2}{|c|}{ Coqueiral } \\
\hline & M. & A. & M. & A. & M. & A. & M. & A. & M. & A. & M. & A. \\
\hline Collembola & $*$ & $*$ & $*$ & $*$ & $*$ & $*$ & $*$ & $*$ & $*$ & $*$ & $*$ & $*$ \\
\hline Coleoptera & $\mathrm{a}$ & $\mathrm{a}$ & $\mathrm{a}$ & a & $\mathrm{a}$ & $\mathrm{a}$ & a & a & $\mathrm{a}$ & $\mathrm{a}$ & $\mathrm{a}$ & a \\
\hline Diptera & $\mathrm{a}$ & $\mathrm{a}$ & $\mathrm{a}$ & $\mathrm{a}$ & $\mathrm{a}$ & $\mathrm{a}$ & $\mathrm{a}$ & $\mathrm{a}$ & $\mathrm{a}$ & $\mathrm{a}$ & $\mathrm{a}$ & $\mathrm{a}$ \\
\hline Ephemeroptera & abcd & abcd & $\mathrm{d}$ & $a b c$ & bcd & $\mathrm{a}$ & abcd & abcd & abcd & $a b$ & $\mathrm{~cd}$ & abcd \\
\hline Hemiptera & $\mathrm{a}$ & $a b$ & $\mathrm{~b}$ & $a b$ & $\mathrm{ab}$ & $a b$ & $a b$ & $\mathrm{~b}$ & $a b$ & $a b$ & $a b$ & $\mathrm{~b}$ \\
\hline Lepidoptera & $\mathrm{b}$ & $a b$ & $\mathrm{~b}$ & $\mathrm{~b}$ & $\mathrm{~b}$ & $a b$ & $a b$ & $a b$ & $a b$ & $\mathrm{a}$ & $\mathrm{b}$ & $\mathrm{b}$ \\
\hline Odonata & $\mathrm{a}$ & $\mathrm{a}$ & $\mathrm{a}$ & $\mathrm{a}$ & $\mathrm{a}$ & $\mathrm{a}$ & $\mathrm{a}$ & $\mathrm{a}$ & $\mathrm{a}$ & $\mathrm{a}$ & a & $\mathrm{a}$ \\
\hline Trichoptera & $\mathrm{abc}$ & $a b c$ & $\mathrm{~cd}$ & $a b c$ & $a b c$ & $\mathrm{a}$ & bcd & $\mathrm{ab}$ & $\mathrm{a}$ & $a b$ & $\mathrm{~d}$ & $\mathrm{abc}$ \\
\hline Bivalvia & $*$ & $*$ & $*$ & $*$ & $*$ & $*$ & $*$ & $*$ & $*$ & $*$ & $*$ & $*$ \\
\hline Gastropoda & $\mathrm{a}$ & $\mathrm{a}$ & $\mathrm{a}$ & $\mathrm{a}$ & $\mathrm{a}$ & $\mathrm{a}$ & $\mathrm{a}$ & $\mathrm{a}$ & $\mathrm{a}$ & $\mathrm{a}$ & $\mathrm{a}$ & $\mathrm{a}$ \\
\hline Hirudinea & $\mathrm{a}$ & $\mathrm{a}$ & $\mathrm{a}$ & $\mathrm{a}$ & $\mathrm{a}$ & $\mathrm{a}$ & $\mathrm{a}$ & $\mathrm{a}$ & $\mathrm{a}$ & $\mathrm{a}$ & $\mathrm{a}$ & $\mathrm{a}$ \\
\hline Oligochaeta & $\mathrm{a}$ & $\mathrm{a}$ & $\mathrm{a}$ & $\mathrm{a}$ & $\mathrm{a}$ & $\mathrm{a}$ & $\mathrm{a}$ & $\mathrm{a}$ & $\mathrm{a}$ & $\mathrm{a}$ & $\mathrm{a}$ & $\mathrm{a}$ \\
\hline Conchostraca & $a b$ & $a b$ & $\mathrm{~b}$ & $\mathrm{~b}$ & $\mathrm{a}$ & $\mathrm{a}$ & $a b$ & $a b$ & $a b$ & $a b$ & $\mathrm{~b}$ & $\mathrm{~b}$ \\
\hline Ostracoda & $a b c$ & bcd & $\mathrm{cd}$ & $\mathrm{ab}$ & $\mathrm{d}$ & abcd & $\mathrm{d}$ & abcd & $\mathrm{a}$ & bcd & abcd & abcd \\
\hline Acariformes & $*$ & $*$ & $*$ & $*$ & $*$ & $*$ & $*$ & $*$ & $*$ & $*$ & $*$ & $*$ \\
\hline Nematoda & $\mathrm{a}$ & $a b$ & $\mathrm{~b}$ & $\mathrm{a}$ & $a b$ & $\mathrm{ab}$ & $a b$ & $\mathrm{ab}$ & $\mathrm{ab}$ & $a b$ & $\mathrm{a}$ & $a b$ \\
\hline
\end{tabular}

(M.= March and A.= August).

Perturbation caused in August by fluctuations in hydrometric levels of the Paranapanema River also provided a high degree of connection with the marginal lakes. This may have favoured the habitat heterogeneity of macroinvertebrate communities and increased species richness in August. Changes in the water chemical and physical characteristics of the lakes as a function of variations in climatic conditions and river water levels probably 
altered the stability and local dynamics. Similar results were reported by Stenert et al. (2003) after evaluation of inundation pulse effects on macroinvertebrates community during an annual cycle in the Low dos Sinos River (Rio Grande do Sul, Brazil). The authors reported that both macroinvertebrate richness and density varied in a marginal lake during the studied period. However, the authors observed that the ecological attributes appeared not to be influenced by flood duration, but that modifications occurred after the inundation, since macroinvertebrate richness and density were higher after the flood event. Trend on an increase of macroinvertebrate density and richness after a flood of long duration was also observed in lakes lateral to the Paranapanema River. Higher values of macroinvertebrate taxa richness and total mean density occurred one month after intense rainfall that affected the natural dynamics of the river water inflow into marginal lakes.

Tawari-Fufeyin et al. (2008), in a study of macroinvertebrates associated with Eichhornia natans, found the highest taxa richness in rainy season, when the nutrients (nitrate and phosphate) presented the highest concentrations.

In present study, the fauna associated with E. azurea in lakes marginal to the Paranapanema River predominated in both periods in class Insecta. Insects use macrophytes as substrates for spawning, development and emergency and are abundant and diversified when living together with aquatic plants. Thomaz and Cunha (2010) verified that changes in community composition, as well as abundance and richness, are influenced by some factors, such as availability of shelters against predators and feeding sites. Poi de Neiff and Neiff (2006) pointed out that other factors are related to macroinvertebrate taxa richness on aquatic plants, such as the macrophyte morphology and texture, light penetration, water circulation, substrate for colonisation by periphyton and ability of retention of particulate organic matter.

Other important factors for the high taxa richness associated with macrophytes are microorganisms, invertebrates and young and small size ichthyofauna components living on roots of aquatic plants, which constitute a food resource for macroinvertebrates and predator fish. Thus, a great number of taxa can be attracted to macrophyte stands, increasing the richness in these sites (Thomaz and Cunha, 2010). The extensive fascicled roots of $E$. azurea can promote a great retention of particulate organic matter and detritus accumulation, favouring the presence of collector animals (Trivinho-Strixino et al., 2000). These macroinvertebrates are food resources for predators. Chironomidae larvae predominated in the six sampled lakes in the two study periods and, together with Oligochaeta, may have attracted other animals on macrophytes stands, contributing to increase the taxa richness. The dominance of Chironomidae associated with macrophytes was also observed by Bogut et al. (2007), Souza-Franco et al. (2009), Silva et al. (2009), Albertoni and Palma-Silva (2006), Moretti et al. (2003), Prellvitz and Albertoni (2004) and Peiró and Alves (2004, 2006). Callisto et al. (2002) reported that Chironomidae has ample distribution in the world and actually are the most numerous family of aquatic insects in freshwater environments.

In the fauna associated with E. azurea in the lakes lateral to the Paranapanema River, the second group in importance in the two periods was constituted by Crustacea and Annelida, being dominated by the Ostracoda and Oligochaeta taxa, respectively. Similar results were obtained by Thomaz et al. (2008) in a study of lakes lateral to the Paraná River. Alves and Gorni (2007), studying oligochaets associated with submersed macrophytes in two reservoirs of São Paulo state, concluded that aquatic plants provide a good substrate for a rich and abundant fauna. Mormul et al. (2006) also verified that during the decomposition of E. azurea and Polygonum ferrugineum, Oligochaeta was the predominant taxa, after Chironomidae in the succession of invertebrates.

However, Higuti et al. (2009) mentioned that the Ostracoda organisms are also abundant in the invertebrate communities associated with macrophytes in Neotropical region. These macroinvertebrates use macrophytes as a substrate for spawning and sites of protection against predators and feeding (Mormul et al., 2010), ingesting algae and detritus through water filtration (Gooderham and Tsyrlin, 2009).

Food supply may also have been affected by the high abundance and richness of other aquatic macroinvertebrates taxa recorded in this study, because morphological characteristics of E. azurea, such as stems with long roots and leaves in contact with water increase the colonisation area by periphyton and the retention of particulate organic matter. These two components are the main food supplies for the majority of the aquatic macroinvertebrates. Thus, the structural complexity of E. azurea roots together with the food supply may have contributed to the colonisation and maintenance of the high richness and abundance of macroinvertebrates observed in the present study.

Knowledge of the biology and ecology of aquatic macroinvertebrates is important for the preservation of biodiversity in continental aquatic ecosystems, since these animals are relevant indicators of priority areas for conservation measures, considering that they are good bioindicators of water quality. Selection of such invertebrates can help in the evaluation of environmental impacts that compromise the ecological integrity of ecosystems. Thus, aquatic macroinvertebrates are extremely useful to complete the information necessary for the protection and recovery of continental aquatic ecosystems, as well as the maintenance of biodiversity in such sites.

Acknowledgements - The first author is grateful to CAPES for the scholarship. FUNDIBIO supported this research financially; Hamilton Antonio Rodrigues and Joaquim Nunes da Costa helped in the field; Laerte José da Silva carried out a revision of the English language. 


\section{References}

AFONSO, AAO., 2002. Relações da fauna associada à Eichhornia azurea (Swartz) Kunth com as variáveis abióticas em lagoas laterais de diferentes graus de conexão ao Rio Paranapanema (zona de desembocadura na Represa de Jurumirim, SP). Botucatu: Instituto de Biociências, Universidade Estadual Paulista. 169 p. Tese de Doutorado em Ciências Biológicas.

AGOSTINHO, AA., THOMAZ, SM. and GOMES, LC., 2005. Conservação da biodiversidade em águas continentais do Brasil. Megadiversidade, vol. 1, no. 1, p. 70-78.

ALBERTONI, EF. and PALMA-SILVA, C., 2006. Macroinvertebrados associados à macrófitas aquáticas flutuantes em canais urbanos de escoamento pluvial (Balneário Cassino, Rio Grande, RS). Neotropical Biology and Conservation, vol. 1, no. 2 , p. $90-100$.

ALVES, RG. and GORNI, GR., 2007. Naididae species (Oligochaeta) associated with submersed aquatic macrophytes in two reservoirs (São Paulo, Brazil). Acta Limnologica Brasiliensia, vol. 19, no. 4, p. 407-413.

BIANCHINI-JUNIOR, I., 2003. Modelos de crescimento e decomposição de macrófitas aquáticas. In THOMAZ, SM. and BINI, LM. (Org.). Ecologia e Manejo de Macrófitas Aquáticas. Maringá: EDUEM. p. 85-126.

BOGUT, I., VIDAKOVIC, J., PALIJAN, G. and ČERBA, D., 2007. Benthic macroinvertebrates associated with four species of macrophytes. Versita, vol. 62, no. 5, p. 600-606.

BRENDONCK, L., MAES, J., ROMMENS, W., DEKEZA, N., NHIWATIWA, T., BARSON, M., CALLEBAUT, V., PHIRI, C., MOREAU, K., GRATWICKE, B., STEVENS, M., ALYN, N., HOLSTERS, E., OLLEVIER, F. and MARSHALL, B., 2003. The impact of water hyacinth (Eichhornia crassipes) in a eutrophic subtropical impoundment (Lake Chivero, Zimbabwe). II. Species diversity. Archiv für Hydrobiologie, vol. 158, no. 3, p. 389-405. http://dx.doi.org/10.1127/0003-9136/2003/0158-0389

CALLISTO, M., MORENO, P., GONÇALVES JUNIOR, JF., LEAL, JJF. and ESTEVES, FA., 2002. Diversity and biomass of Chironomidae (Diptera) larvae in an impacted coastal lagoon in Rio de Janeiro, Brazil. Brazilian Journal of Biology, vol. 62, no. 1, p. 77-84. http://dx.doi.org/10.1590/S1519-69842002000100010

CARMO, CF., 2007. Influência do aquífero freático na dinâmica de nutrientes (nitrogênio e fósforo) em lagoas com diferentes características hidrodinâmicas. São Paulo: Escola de Engenharia de São Carlos da Universidade de São Paulo. 257 p. Tese de Doutorado em Ciências da Engenharia Ambiental.

CASANOVA, SMC. and HENRY, R., 2004. Longitudinal distribution of Copepoda populations in the transition zone of Paranapanema River and Jurumirim Reservoir (São Paulo) and interchange with two lateral lakes. Brazilian Journal of Biology, vol. 64, no. 1, p. 11-26. http://dx.doi.org/10.1590/S1519-69842004000100003

CREMONA, F., PLANAS, D. and LUCOTTE, M., 2008. Biomass and composition of macroinvertebrate communities associated with different types of macrophyte architectures and habitats in a large fluvial lake. Archiv für Hydrobiologie, vol. 171, no. 2, p. 119-130.

DAJOZ, R., 2005. Princípios de Ecologia. Porto Alegre: Artmed. 519 p.

DE MARCO-JÚNIOR, P. and VIANNA, DM., 2005. Distribuição do esforço de coleta de Odonata no Brasil - subsídios para escolha de áreas prioritárias para levantamentos faunísticos. Lundiana, no. 6 (supplement), p. 13-26.

ESTEVES, FA., 2011. Fundamentos de Limnologia. 3. ed. Rio de Janeiro: Interciência. 826 p.

GOODERHAM, J. and TSYRLIN, E., 2009. The Waterbug Book: a Guide to the Freshwater Macroinvertebrates of Temperate Australia. Australia: CSIRO Publishing. 232 p.

GOLTERMAN, KL., CLYMO, RS. and OHMSTAD, MAM., 1978. Methods for physical and chemical analysis of freshwaters. 2. ed. Oxford: Scientific Publications. 213 p.

GONÇALVES-JUNIOR, JF., SANTOS, AM. and ESTEVES, FA., 2004. The influence of the chemical composition of Typha domingensis and Nymphaea ampla detritus on invertebrate colonization during decomposition in a Brazilian coastal lagoon. Hydrobiologia, vol. 527, p. 125-137. http://dx.doi.org/10.1023/ B:HYDR.0000043190.49651.dc

GRANADO, DC. and HENRY, R., 2008. The influence of the hydrologic pulse on the water physical and chemical variables of lateral lakes with different connection levels to Paranapanema River in the mouth zone at Jurumirim Reservoir (São Paulo, Brazil). Acta Limnologica Brasiliensia, vol. 20, no. 4, p. 265-275.

HENRY, R., 2005. The connectivity of the Paranapanema River with two lateral lakes in its mouth zone into the Jurumirim Reservoir. Acta Limnologica Brasiliensia, vol. 17, no. 1, p. 57-69.

HENRY, R. and COSTA, MLR., 2003. As macrófitas como fator de heterogeneidade espacial: um estudo em três lagoas com diferentes conectividades com o rio Paranapanema. In THOMAZ, SM. \& BINI, LM. (Org.). Ecologia e Manejo de Macrófitas Aquáticas. Maringá: EDUEM. p.189-210.

HIGUTI, J., LANSAC-TÔHA, FA., VELHO, LFM., PINTO, RL., VIEIRA, LCG. and MARTENS, K., 2009. Composition and distribution of Darwinulidae (Crustacea, Ostracoda) in the alluvial valley of the upper Paraná River, Brazil. Brazilian Journal of Biology, vol. 69, no. 2, p. 253-262. http://dx.doi.org/10.1590/ S1519-69842009000200004

LAKE, PS., 2000. Disturbance, patchiness, and diversity in streams. Journal of the North American Benthological Society, vol. 19, no. 4, p. 573-592. http://dx.doi.org/10.2307/1468118

LOPRETTO, EC. and TELL, G., 1995. Ecosistemas de aguas continentales: Metodologias para su estudio. Argentina: Ed. Sur. La Plata. tomo III, p. 897-1397.

MARTELLO, AR., NUNES, IGW., BOELTER, RA. and LEAL, LA., 2008. Malacofauna límnica associada à macrófitas aquáticas do rio Iguariaçá, São Borja, RS, Brasil. Ciência e Natura, vol. 30, no. 1 , p. $27-41$

McCABE, DJ. and GOTELLI, NJ., 2000. Effects of disturbance frequency, intensity, and area on assemblages of stream macroinvertebrates. Oecologia, vol. 124, p. 270-279. http:// dx.doi.org/10.1007/s004420000369

MORETTI, MS., GOULART, MDC. and CALLISTO, M., 2003. Avaliação rápida da macrofauna associada à Eichhornia azurea (Swartz) Kunth, 1843 e Pontederia lanceolata Nutt., 1818 (Pontederiaceae) na Baía do Coqueiro, Pantanal de Poconé (MT/ Brasil). Revista Brasileira de Zoociências, vol. 5, no. 1, p. 7-21.

MORMUL, RP., THOMAZ, SM., HIGUTI, J. and MARTENS, K., 2010. Ostracod (Crustacea) colonization of a native and a non-native macrophyte species of Hydrocharitaceae in the Upper Paraná floodplain (Brazil): an experimental evaluation. 
Hydrobiologia, vol. 644, p. 185-193. http://dx.doi.org/10.1007/ s10750-010-0112-3

MORMUL, RP., VIEIRA, LA., PRESSINATTE, SJ., MONKOLSKI, A. and SANTOS, AM., 2006. Sucessão de invertebrados durante o processo de decomposição de duas plantas aquáticas (Eichhornia azurea e Polygonum ferrugineum). Acta Scientiarum. Biological Sciences, vol. 28, no. 2, p. 109-115.

MUGNAI, R., NESSIMIAN, JL. and BAPTISTA, DF., 2010. Manual de Identificação de Macroinvertebrados Aquáticos do Estado do Rio de Janeiro. Rio de Janeiro: Technical Books Editora. $176 \mathrm{p}$.

NESSIMIAN, JL. and HENRIQUES-OLIVEIRA, AL., 2005. Colonização do "litter" de Eleocharis sellowiana Kunth. (Cyperaceae) por larvas de Chironomidae (Diptera) em um brejo no litoral do estado do Rio de Janeiro. Entomologia y Vectores, vol. 12, no. 2, p. 159-172.

ODUM, EP. and BARRETT, GW., 2007. Fundamentos de Ecologia. Tradução da 5. ed. Norte-americana. São Paulo: Cengage Learning. 612 p.

PADIAL, AA., BINI, LM. and THOMAZ, SM., 2008. The study of aquatic macrophytes in Neotropics: a scientometrical view of the main trends and gaps. Brazilian Journal of Biology, vol. 68, no. 4 (suplemento), p. 1051-1059.

PEIRÓ, DF. and ALVES, RG., 2004. Levantamento preliminar da entomofauna associada à macrófitas aquáticas da região litoral de ambientes lênticos. Revista da Uniara, no. 15, p. 177-188.

-, 2006. Insetos aquáticos associados à macrófitas da região litoral da represa do Ribeirão das Anhumas (município de Américo Brasiliense, São Paulo, Brasil). Biota Neotropica, vol. 6, no. 2, p. 1-9.

POI DE NEIFF, A. and NEIFF, JJ., 2006. Riqueza de especies y similaridad de los invertebrados que viven en plantas flotantes de la Planicie de Inundación del Río Paraná. Interciência, vol. 31, no. 3, p. 220-225.

PRELLVITZ, LJ. and ALBERTONI, EF., 2004. Caracterização temporal da comunidade de macroinvertebrados associada à Salvinia spp. (Salviniaceae) em um arroio da Planície Costeira de Rio Grande, RS. Acta Biologica Leopoldensia, vol. 26, no. 2, p. 213-223.

SÁNCHEZ-BOTERO, JI., LEITÃO, RP., CARAMASCHI, EP. and GARCEZ, DS., 2007. The aquatic macrophytes as refuge, nursery and feeding habitats for freshwater fish from Cabiúnas Lagoon, Restinga de Jurubatiba National Park, Rio de Janeiro, Brazil. Acta Limnologica Brasiliensia, vol. 19, no. 2, p. 143-153.

SILVA, FH., FAVERO, S., SABINO, J. and GARNÉS, SJA., 2009. Distribuição da entomofauna associada às macrófitas aquáticas na vazante do rio Correntoso, Pantanal do Negro, Estado do Mato Grosso do Sul, Brasil. Acta Scientiarum. Biological Sciences, vol. 31, no. 2, p. 127-134.

SOUZA-FRANCO, GM., ANDRIAN, IF. and FRANCO, RM., 2009. Comunidade de insetos aquáticos associados à
Eichhornia azurea (Schwartz) Kunth, em uma lagoa de várzea na planície de inundação do Alto Rio Paraná, Mato Grosso do Sul, MS, Brasil. Biológico, vol. 7, no. 1, p. 83-91.

STENERT, C., SANTOS, EM. and MALTCHIK, L., 2003. Os efeitos do pulso de inundação na comunidade de macroinvertebrados em uma lagoa associada a uma planície de inundação do sul do Brasil. In HENRY, R. (Org.). Ecótonos nas Interfaces dos Ecossistemas Aquáticos. São Carlos: Rima. p. 47-60.

STRIPARI, NL. and HENRY, R., 2002. The invertebrate colonization during decomposition of Eichhornia azurea Kunth in a lateral lake in the mouth zone of Paranapanema River into Jurumirim Reservoir (São Paulo, Brazil). Brazilian Journal of Biology, vol. 62, no. 2, p. 293-310. http://dx.doi.org/10.1590/ S1519-69842002000200014

TAKEDA, AM., SHIMIZU, GY. and HIGUTI, J., 1997. Variações espaço-temporais da comunidade zoobêntica. In VAZZOLER, AEAM., AGOSTINHO, AA. and HAHN, NS. (Org.). A Planície de inundação do alto rio Paraná: aspectos físicos, biológicos e socioeconômicos. Maringá: EDUEM, Nupélia. p. 157-177.

TAWARI-FUFEYIN, P., ILOBA, BN. and UNUAJOHWOFIA, E., 2008. Evaluating the water quality of Ossiomo River using macro invertebrates associated with water hyacinth (Eichhornia natans). Bioscience Research Communications, vol. 20, no. 6, p. 283-291. http://dx.doi.org/10.1590/S0373-55241962000300006

TEIXEIRA, C. and KUTNER, MB., 1962. Plankton studies in a mangrove environment. I - First assessment of standing stock and ecological factors. Boletim do Instituto Oceanográfico, vol. 12, p. 101-124.

TESSIER, C., CATTANEO, A., PINEL-ALLOUL, B., GALANTI, G. and MORABITO, G., 2004. Biomass, composition and size structure of invertebrate communities associated to different types of aquatic vegetation during summer in Lago di Candia (Italy). Journal of Limnology, vol. 63, no. 2, p. 190-198. http://dx.doi. org/10.4081/jlimnol.2004.190

THOMAZ, SM. and CUNHA, ER., 2010. The role of macrophytes in habitat structuring in aquatic ecosystems: methods of measurement, causes and consequences on animal assemblages composition and biodiversity. Acta Limnologica Brasiliensia, vol. 22, no. 2, p. 218-236. http://dx.doi.org/10.4322/actalb.02202011

THOMAZ, SM., DIBBLE, ED., EVANGELISTA, LR., HIGUTI, J. and BINI, LM., 2008. Influence of aquatic macrophyte habitat complexity on invertebrate abundance and richness in tropical lagoons. Freshwater Biology, vol. 53, p. 358-367.

TRIVINHO-STRIXINO, S., CORREIA, LSC. and SONODA, K., 2000. Phytophilous Chironomidae (Diptera) and other macroinvertebrates in the ox-bow Infernão Lake (Jataí Ecological Station, Luiz Antônio, SP, Brazil). Revista Brasileira de Biologia, vol. 60 , no. 3, p. 527-535. http://dx.doi.org/10.1590/S003471082000000300018

TUNDISI, JG., and MATSUMURA-TUNDISI, T., 2008. Limnologia. São Paulo: Oficina de Textos, 631 p. 